\title{
AN ASSESSMENT OF THE FLOK PROCESS AND WHY THE P2P FOUNDATION WILL NOT USE THE FLOK BRAND IN THE FUTURE
}

\section{Michel Bauwens}

(this version was originally written at the request of Jay Wallsjasper of On the Commons)

\begin{abstract}
Experience report on the implementation of P2P process, collaboration and knowledge sharing, called flok (Free/Libre Open Knowledge) in Equator. In the face of difficulties, we highlight the government's reluctance to give effective support, not considered strategic. Often, in order not explicit, the government claims to support but eventually affects the progress of the project. Another challenge faced was mistrust of civil society on a project allegedly sponsored by the government. With the Ecuadorian experience, the author concludes that the FLOK process should not be deployed in future P2P plans and must consider issues such as political and historical context of the country in the next projects.
\end{abstract}

Keywords

Flok Brand. Flok Process. Flok Society. Equator

\section{UMA AVALIAÇÃO DO PROCESSO FLOK E POR QUE A FUNDAÇÃO P2P NÃO USARÁ A MARCA FLOK NO FUTURO}

\section{Resumo}

Relato de experiência na implementação do processo $P 2 P$, de colaboração e compartilhamento de conhecimento, denominado FLOK (Free/Libre Open Knowledge) no Equador. Diante das dificuldades encontradas, destaca-se a resistência do governo em dar efetivo apoio, considerado não estratégico. Muitas vezes, de forma não explicita, o governo diz apoiar, mas prejudica o andamento do projeto. Outro desafio encontrado foi a desconfiança da sociedade civil diante de um projeto supostamente patrocinado pelo governo. Com a experiência do Equador, o autor conclui que o processo FLOK não deve ser implantado em futuros planos $P 2 P$, devendo-se considerar questões como contexto político e histórico do país nos próximos projetos. Palavras-chave Marca Flok. Processo Flok. Sociedade Flok. Equador.

We're nearing the end of June, the day of my departure from Quito and my direct involvement in the FLOK process, where I have been director of the research team. Many people have asked about my assessment of the results of the process. The FLOK process was a complex process and the assessment can only be complex as well.

One of the first questions, and critiques, is about the relationship with the government itself.

Let us start with the general statement that there are only very imperfect governments

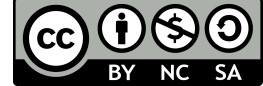


in the world, and that power politics are everywhere difficult and rather unpleasant processes. Nevertheless, if we compare the achievements and workings of the government here, then Ecuador has made significant achievements since the advent of power of the Correa administration. The control over the state and the government by private business has been significantly reduced; state-led redistribution and infrastructure building has significantly improved the economic situation of most of its citizens. There have been significant improvements in poverty, literacy, education, crime, etc.

Political stability and popular endorsement of government policies are significantly higher than in the very unstable neoliberal period that preceded it. The state and many institutions have been modernized.

The new press legislation has reduced corporate control and created a whole new sector of community-based radios and media outlets.

On the other hand, there seems to be a growing schism between civil society actors and a government that was originally derived from it. The government has embarked on an extractivist policy against its own promises and plans (Yasuni), disbanded oppositional civil organizations like the Pachamama Foundation, and exerted pressures against critics in the press. There is a growing schism between the beautiful and enthusing political programs and principles as expressed in the Constitution and the National Plan, and the actual policies that are often contrary to it, and many of those that believed in these ideas are increasingly isolated in institutions like Senplades and Senescyt. They are losing power and influence. The radical sounding 'neo-socialist' language of the government is not matched by structural reforms that go into the direction of anything that is beyond capitalism. On the contrary, the real policies, even though to the left of European social-democracy, are essentially redistributionist and actually aim to create better conditions for capitalist development. The poor are less poor, a middle class is being created, but the economic policies do not fundamentally challenge the global political economy. The current direction seems to be towards more adaptation to the demands of the global system. But there is no doubt that the situation of the country and its people has improved.

When we started the FLOK process, it was presented to us as a project that was strategic for the Ecuadorian government, as supported by the Ministry of Knowledge and the Secretariat of Innovation and would systematically move the country to a social knowledge economy, and that would be enthusiastically received by civil organizations. The reality we encountered was quite different. First of all, despite an intensive effort at participation, and many meetings with local groups, the general attitude of civic organizations was, though 
sympathetic for the aims of FLOK, at the same time distrustful of it as a governmentsponsored project. The pressure for participation came from us, not from civil society.

Our experience with the government was very problematic from the start. First of all, because of factional fighting within and without the institution we were formally working for (IAEN), the staff of the project remained unpaid for 3-5 months, until the end of March, with an active and successful campaign to defund the FLOK. At one point, we were prepared to leave at the end of March because the funding had been cut, and we were all facing extremely challenging material situations. Once the factional fight was concluded with the departure of the rector who had initiated FLOK (Carlos Prieto), we were refunded, and funds were also liberated for the Buen Conocer Summit at the end of May. Our personal and collective situation dramatically improved from that point onwards.

Nevertheless, as research director of the FLOK team, in charge of a theoretically strategic project, I was at no time able to meet with any of our sponsoring ministers. All planned meetings (more than a dozen) between myself and Rene Ramirez and Guillaume Long, were systematically cancelled. The very day before the launch of the Buen Conocer Summit on May 27th, it transpired that the Minister of Knowledge had forbidden his staff to participate in the summit (he reversed this decision on that very last day); and that President Correa had not been aware of the FLOK process at all (I have this info from a person in the Communications Dept. of the President and several other witnesses).

Whatever the reasons for this state of affairs, the only realistic conclusion is that this was not considered as a strategic project. To this day, because we were unable to have conversations with our nominal sponsors, we can ony speculate as to the real motivations.

Nevertheless, we have to look at the positive aspects of the government's involvement as well. First of all, the project was indeed funded, and nowhere else in the world could it have taken place at this stage. Second, we operated in total freedom: the research team was entirely free in its research and proposals, with zero interference. Third, and this is very important for the future of our recommendations, there has been distinct enthusiasm for the aims and process of the FLOK from lower level officials in several governmental institutions, with concrete efforts to fund and carry out important pilot projects.

And, even though the pressure and social basis of the FLOK process was weak in civil society, there was nevertheless a quite intense participatory process. 24 provincial workshops were held with actors from civil society; several multi-day visits to poorer communities were organized with intense mutual exchanges; participatory lectures were held in different institutions with high interest and attendance; workshops were held in various universities. 
All this input was integrated in the first drafts of our proposals. (An open letter to global commoners also yielded several dozen proposals). The highlight was a stay in Sigchos, the country's third poorest district, where we met an enthusiastic mayor (Mario Andino) and a supportive local assembly of the people eager to apply open agricultural projects. This gave us a clear indication that with dynamic leadership, the local people that matter (mostly indigenous and farmers), where totally behind the key ideas of a transition to a commonsbased society, and endorsed its logic and potential. The second phase of the participatory process entailed open commentary on digital comments, yielding many useful suggestions.

But finally, what was very important was the success of the Buen Conocer summit May 27 to 30. The combination of local civic invitees, committed pubic officials, and foreign guests led to a very enthusiastic social dynamic in which the FLOK proposals were substantially improved.

One of the key lessons though is that we have to abandon the romantic idea that we can 'hack a country'. A country, and its people, are not an executable program. For future projects, it will be necessary to ascertain with more due diligence, the maturity of both the political will and the social basis of such a transition. Commons transition programs should be embarked upon as a more clear co-production process, and not undertaken as political gamble. Commons transition should be bottom-up supported processes, enabled and facilitated by supportive public authorities (or without them if that support is not forthcoming).

One of the important lessons of the project is how not to administer it in the future. The administrative process was a purely hierarchical one, with personalistic and secretive control of the budget and decisions. The research team was entirely shut out of the design and organization of the Summit for example. Simple requests for information were not looked kindly upon and were seen as interference. People who disagreed with management did not just have to arbitrarily and unilaterally leave the project, without any due process, but were maligned and subject to active disinformation campaigns involving charges of spying etc ... I was subjected to public threats to publish private emails in order to discourage any independent evaluation, which is what prompted to add this specific paragraph about the internal workings of the FLOK process. Engagements to third parties were routinely changed and unilaterally adapted created all kinds of embarassements towards those parties and endangering our trust and reputational capital. There was a regular use of private and public intimidation, including a threat of physical intimidation during the very summit, including against members of the research team to discourage them from sharing their point of view on 
the public discussion list. Strategically mistaken decisions, such as the defunding of the spanish translation of the Commons Transition Plan, were made from narrow political reasons. Such practices clearly should not have a place in future projects and are one of the reasons the P2P Foundation will not use the FLOK moniker and 'brand' in future Commons Transition projects. We believe our internal practices should be prefigurative of the kind of society we are aiming for and not in contradiction to it. This is how the research team functioned, and in the future, it is how a whole project should function. Our aim here therefore is not to inflame conflicts, but rather to warn third parties of a potential systemic flaw in the approach to such projects: authoritarianism can have no place in open and participatory transition projects.

Nevertheless, despite the problems and failures in Ecuador, along with the relative success we tried to describe above, we can hope that seeds of new thinking about transformation have been sown, and that some pilot projects will be successfully carried out.

Indeed, the FLOK project also has a global impact, and I am quite optimistic about this. First of all, this is the first time that an integrated Commons Transition Plan has been crafted, representing a new political and policy orientation towards achieving a post-capitalist society based on shared knowledge, that has both a theoretical underpinning, and fifteen concrete legislative frameworks. This means that from now on, a concrete third way that is different from both statism and neoliberalism, does exist and can be discussed. Despite the local difficulties of the process, we believe that because of the relative legitimacy and credibility involved in a national project, the commons transition is now a geo-political fact, it's a historical pivot. This assessment is confirmed by the consistent interest that is expressed towards the project, with inquiries of cities and regions as to the possibility of other transition projects. The FLOK is now both a participatory and scientific research process, and a already existing body of work, that can be creatively adapted (and changed, or abandoned altogether), in other locales. The emerging commons, sharing, and $\mathrm{p} 2 \mathrm{p}$ movements can now be more than concrete local practice of grassroots communities, they can become a force for social change at the political and policy level.

The value of the experience in Ecuador, with all the people that contributed to it, is that it signifies a new beginning, the creation of a new social imaginary about commons oriented transition towards a sustainable and more just society. The clock is now ticking, and the arrow of time cannot be reversed. We are beginning to find a politics and policy for the 21 st century. This is not a minor achievement and I am proud I have been able to contribute to it. 
I urge people to have a serious look at the Commons Transition Plan, and to think about the new political concepts that are the expression of the nascent and growing global commons movement.

The proposals are here at http://en.wiki.floksociety.org/w/Research_Plan.

Let's improve them continuously and produce a pattern language for successful social change.

\section{BIBLIOGRAPH}

P2P Foundation. Flok Society Project. Disponível em: $<$ http://p2pfoundation.net/

FLOK_Society_Project \#Evaluation_by_Michel_Bauwens>. Acesso em: 20 Dez 2015. 